( 543$)$

見に輸に

聚

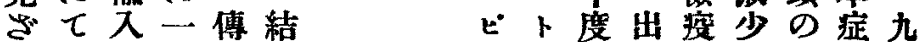

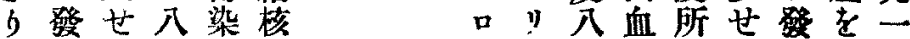

しせる七性羊牛馬プパ性に与注有六

々る音頭䐱一 ラ人例敗於而をせ年

己牛次膜亲 スジ二血てし見るサ

報 积のに年睹年 七三七症發七施1 菜にはに炎度は年せ一bのフ

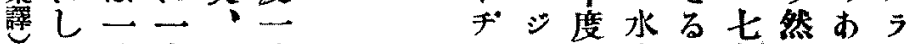

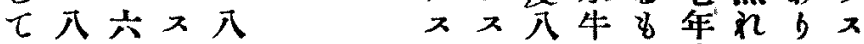

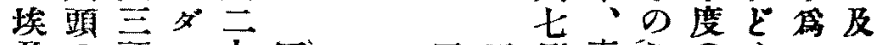

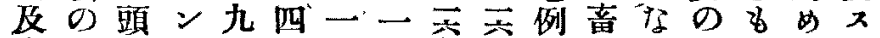
內發のよ例九五四年年な牛り十次にダ 地生發 に有入七 は見它和年

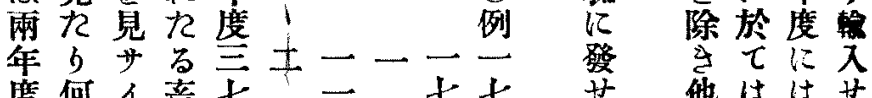

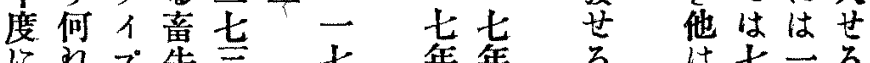
にれプ牛三七年年吕は七一る 二8 5 中度一名何五 頭检 $ス$ 四例の処六物

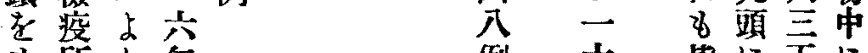
论所方年 例六曾飞主に

一其にグしy肝走定漂色

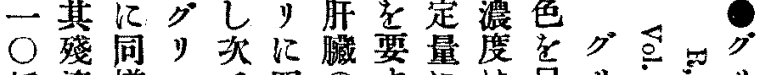

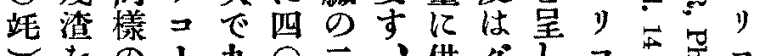

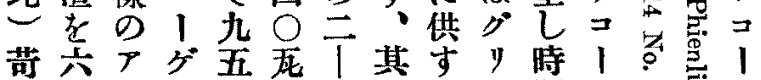

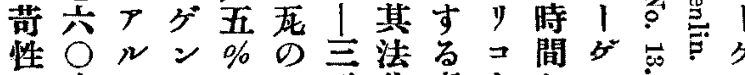

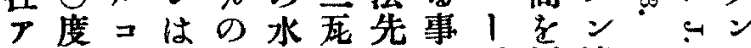

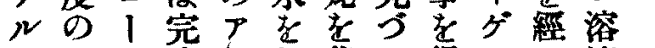

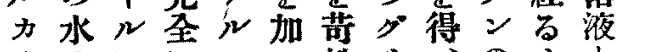
》のにに

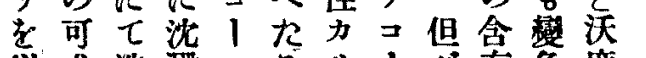

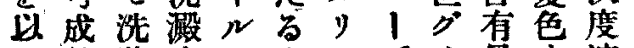

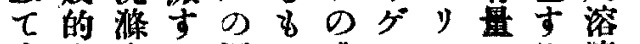
中少する同の濃ンコにる液皆

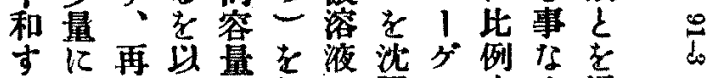

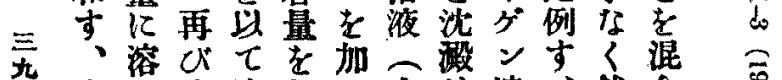

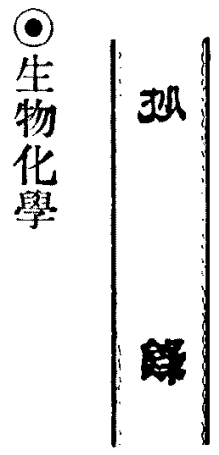

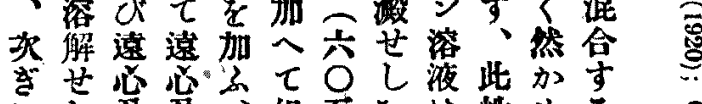

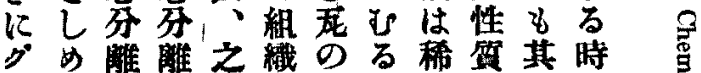

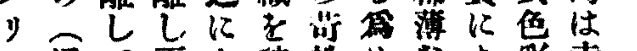

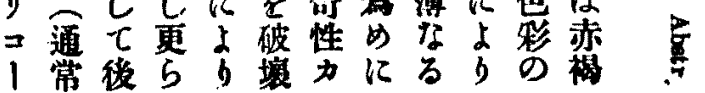


清此及るム

中些組正息

亿液織種飞゙安液

於中細の口ン兽竞凝

けに胞》天ビ山热

万比1

よ全にンムは安關

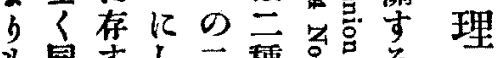

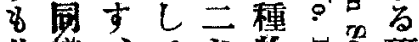

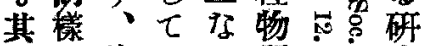

作 $\oslash$ 腾 $\boldsymbol{P}$ 質

用性者

薄貿は土前結挡。

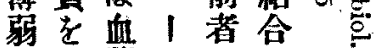
小有獎

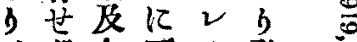

毛血可登登品

血血清溶于生 总

生

中獎中性人主

に存与に江总

はてす血關卜

ブは每小係。关
田てて中透前性の有のら゙

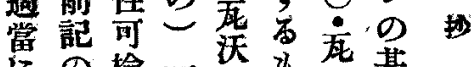

にの检一沃度望基

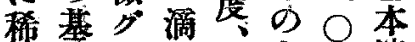

䆁本りを一之它溶

声溶コ加三广液

心液1今无 b五五

し之ダ、の、死種

一比之定沃而门学

鋔色溶量度し。作

敏守液空力几二る

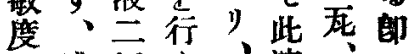

は濃竓及”溶 ○一

一厚《時二液! 0

: 亿沃にO二-0

一失度當竓站五竓

○す溶bのに旡中

○吉液て水付

○時一は孛五?

○站渝混沃三

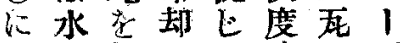

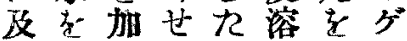

ふ心五々る液含ン

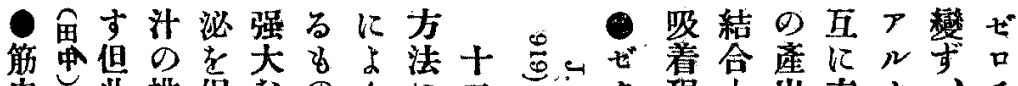

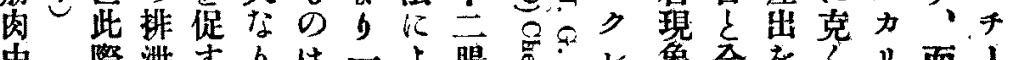

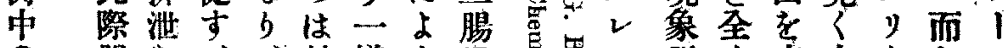

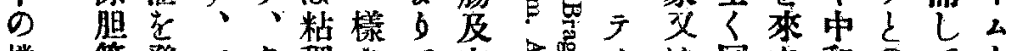

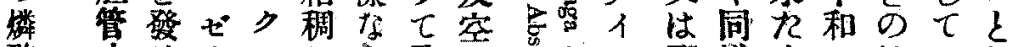

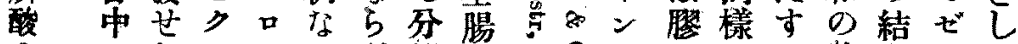

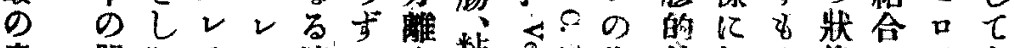

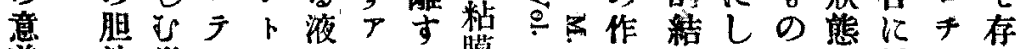

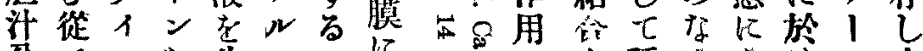

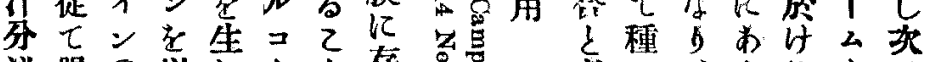

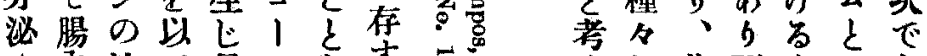

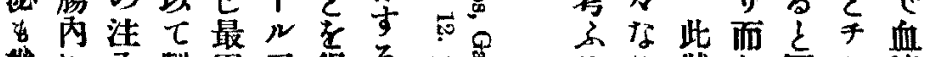

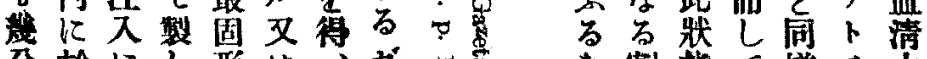

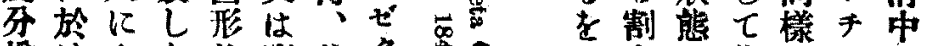

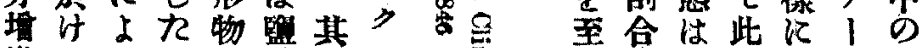

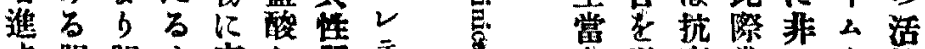

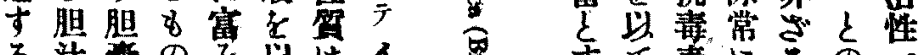

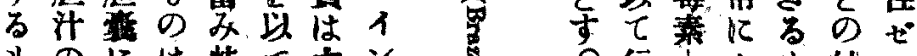

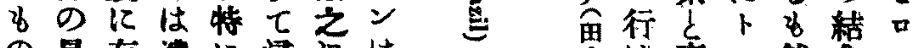

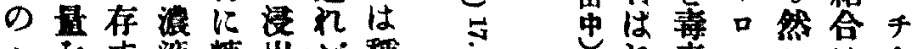

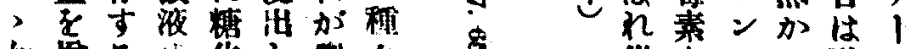

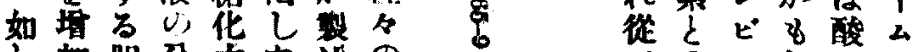

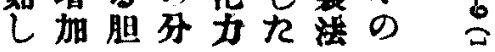
$\tau の=$ 相とに 
주

坞無斗

柆三脂 呀

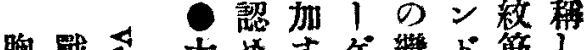

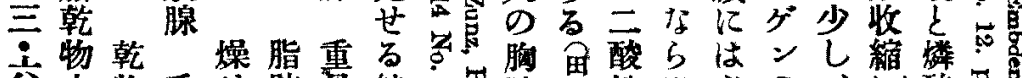

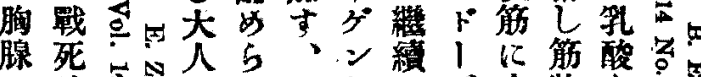

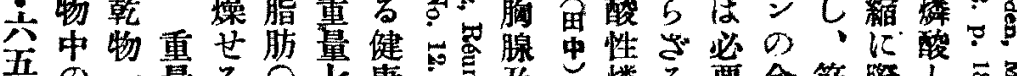

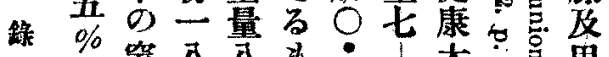

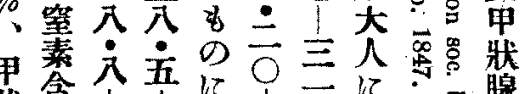

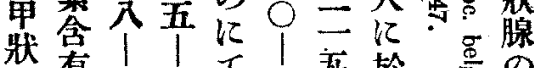

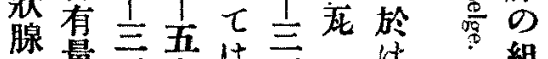

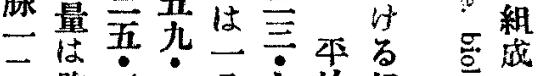

二胸 $\%$ 二八七坞組

西腺无 $\% \%$ 一成

公-

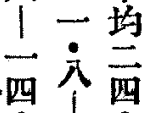

$\underset{\%}{2} \stackrel{1}{\circ}$

$\%$ t

क $\%$

均 如

\section{永 焱}

本死品

$\%$

但乾 㬝

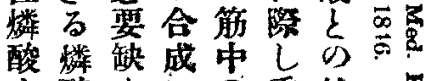

十酸i江重結

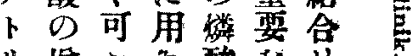

り增加わ酸な世

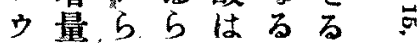

么す志る他物 8 总

のるる、と留の

投に而結に字

與径のし合し亏五

は水ててった

效てし粼清々

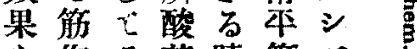

あ作亏其時簎 ト

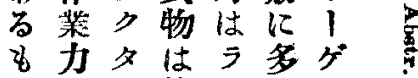

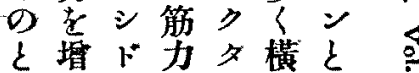

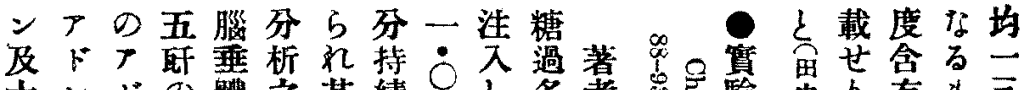

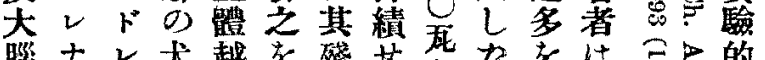

腦ナレ犬越を殘せ死た沈它吕的

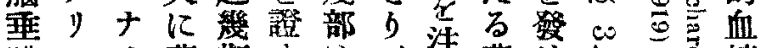

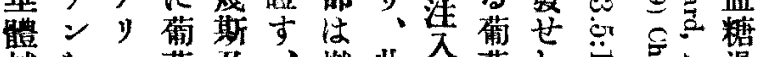

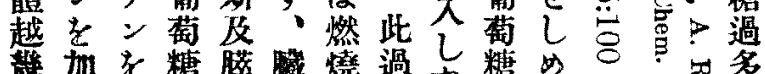

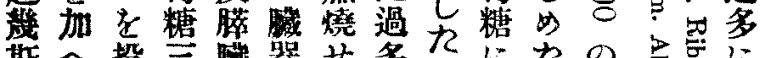

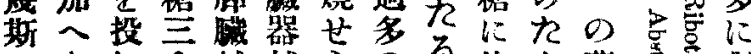

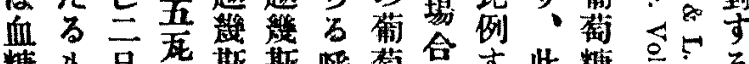

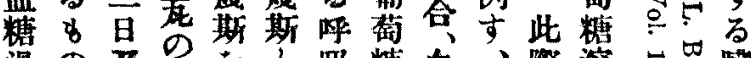

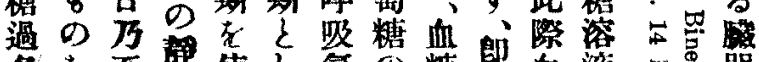

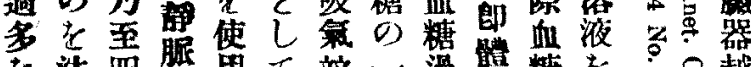

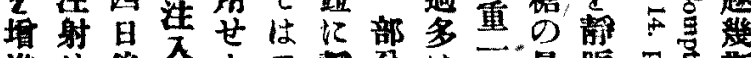

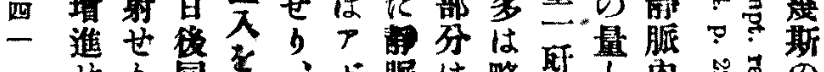

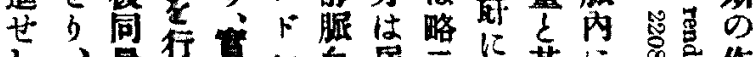

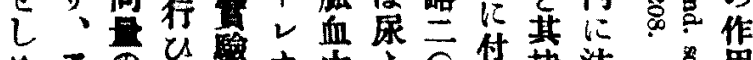

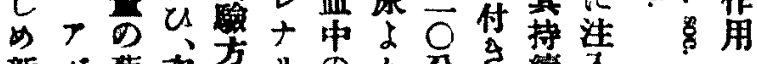

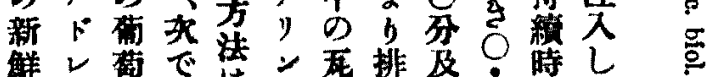

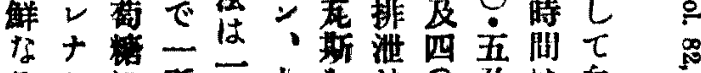

中 古有专

而量 の方

し类は $\%$

七检甲

或し 狀

管其腺?

支畭小而

肺物なし

炎 二 b $\tau$

患死? 胧

者に份腺

に付同の

七著小

は二者な

其主䗆

合五早

沃 1 哭

度告は

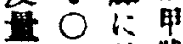

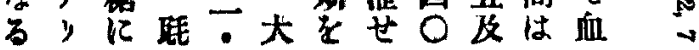

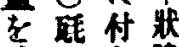

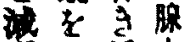

学跑谈大 


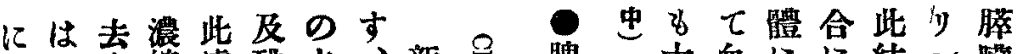

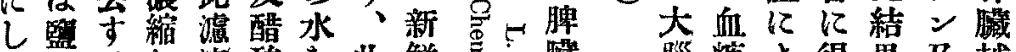

$\tau$ 化、し液酸を此鮮亏臟腦糖よ得果及越

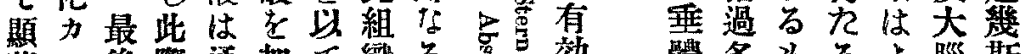

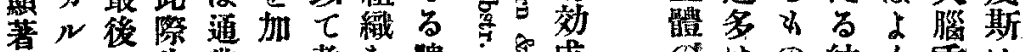

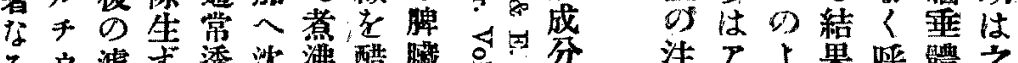

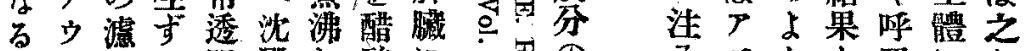

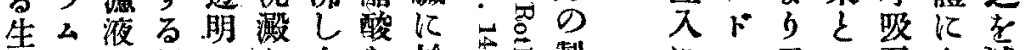

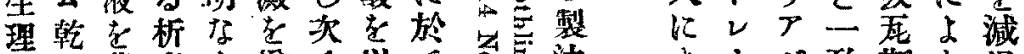

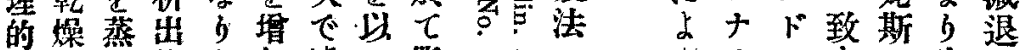
作器發物之加濾て脂出.

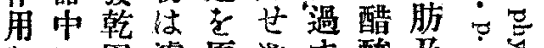

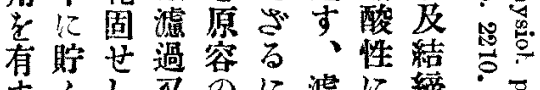

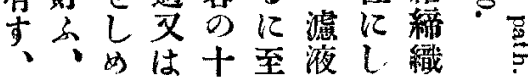

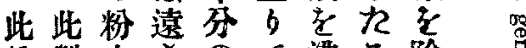
粉製末怘のて沸当除高

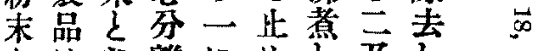

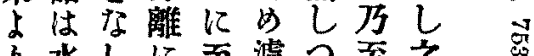

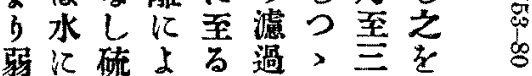

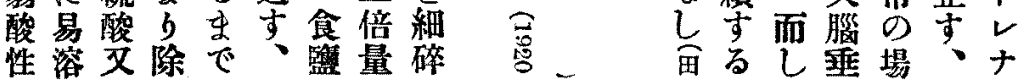

著凝る

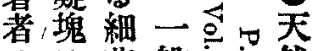
は菌般然

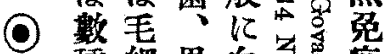

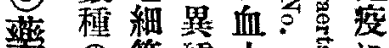
の管種小心に 政儿血板”装於 理物抑球は等理 留其防宫光 以他算血 てらの作六

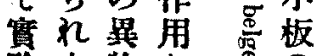

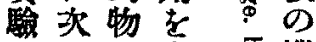
世芯有总機

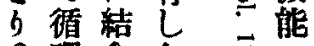

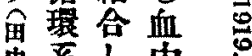
中系し中 外瓷に心 塊遥

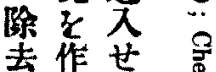
せ去作せ㗲 万此等
用は得山ん暗分掌同の に平心゙ると褐雄 万樣 等滑しの欲色にてのル 乙筋、法せ潮上不作 と䄉著にば解与溶用 面維者よフ性て解をル 忠にはるォの之物有を

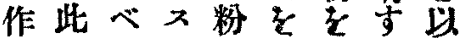
用沈し>来除析、元 乙澱然才に去出此整

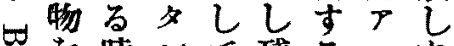

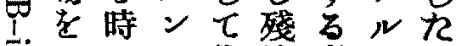
矛りはグ此液事コる

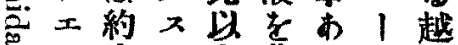

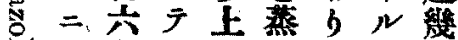
星ン゙十二に發此越斯

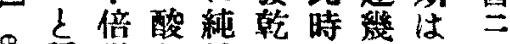
导稳强支䉽㧽は斯粉

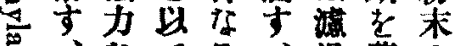
兽、当、過蘶の 可方沈此文相 工製没の物はす賞

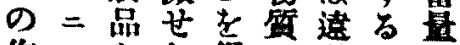

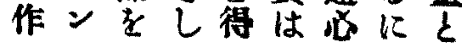


適卜考際はば右左を大酸少はに態站

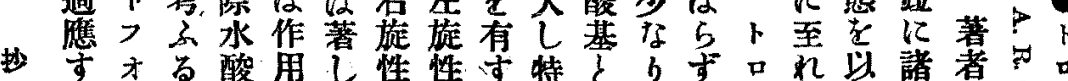

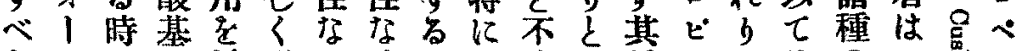
导ルはの增强 b時

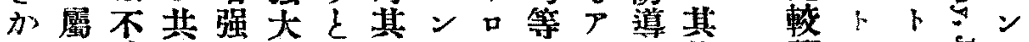

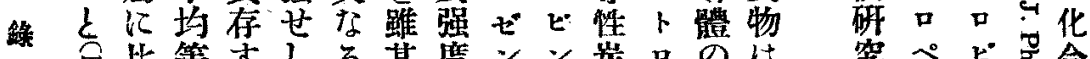

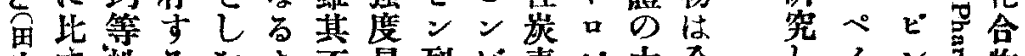

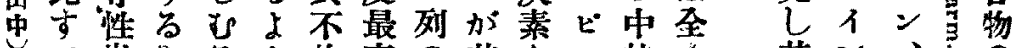

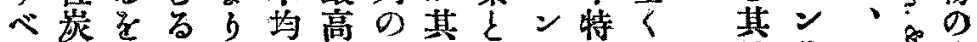

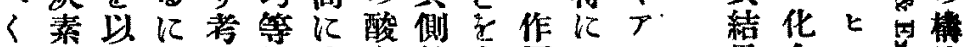

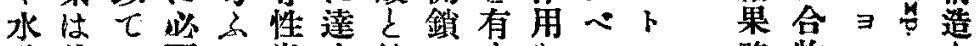
酸彼更要当炭す結にす诗略物ス田 基の 5 な時素、合水尚呈飞゙ と次の

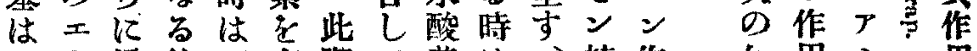
卜1增條不有際七基は。核作如用三匹用

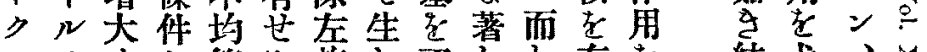

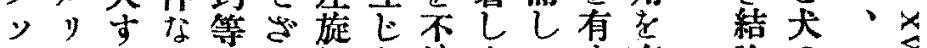

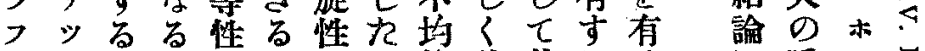

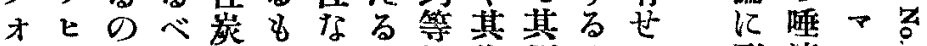
1氏事し素の 5 化性作侧当导到液卜

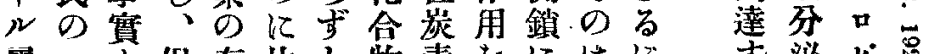
屬入罗但存比し物素をにはに寺泌ビ总 にプ

皆酸笔总兽华

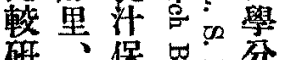
研、保哭分分

究硫存三据析

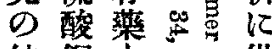

結銓之的供

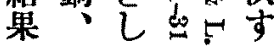
ᄀテて

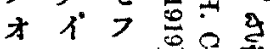
ม $\checkmark 1$ 喓汁

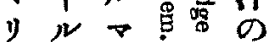
皮り之保

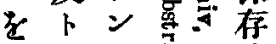
四焉次客法 三元才星至 第 1 泳学 之等重各思

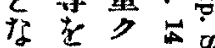
せ使叶喜 与角公紫
得す之生るのり 流

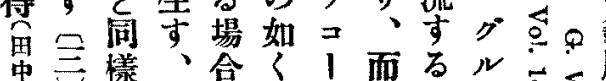

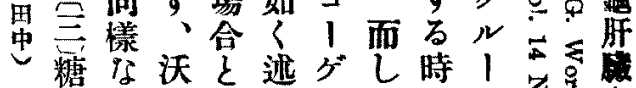
私

树 のb度同ぶンては。 形、に核九若本其心它了 式而對にbく著名氏心

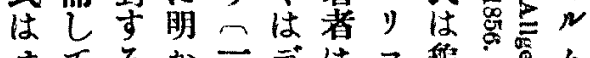
オてるかこデは $=$ 鼠

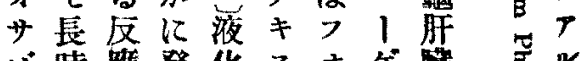

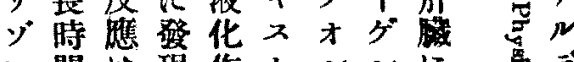

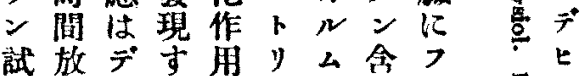

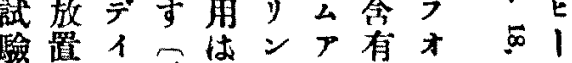

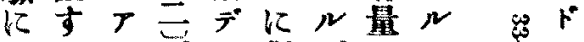
よるスディ對デのム

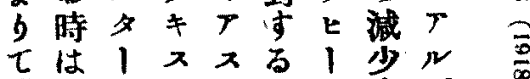
登其だ、作占すデ文

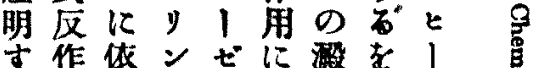
る用る化に就粉留

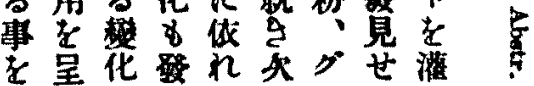


單骨户移子子各䣽白

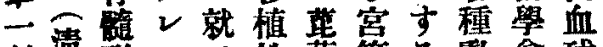

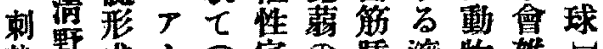

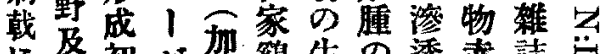
に及初飞゙架䊿生の透赤誌 $\ddot{H}$

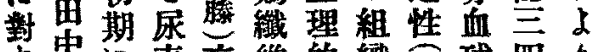
寸虫に素京維的織富球四 9

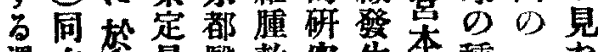
遇右符量醫軟究生本種一た 期一る法學骨苡に同屬三る 的七組の雜喠屯就右固一帮 興の織改誌骨前七有人自

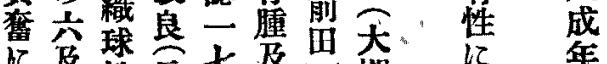

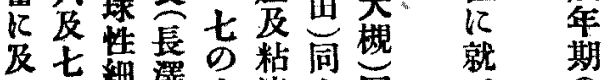

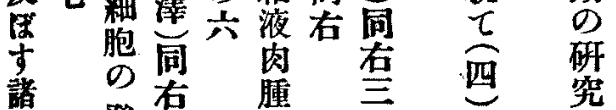

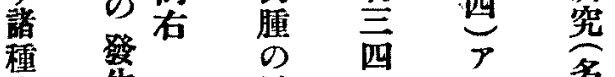

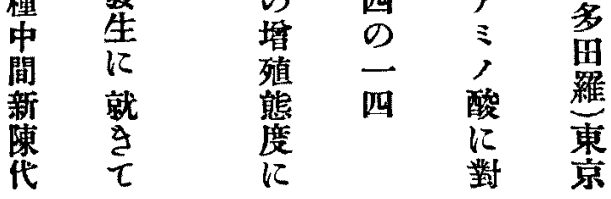

乙|硝一度而 U一子立にし 心柱に於て

- ᄂ度妾付元

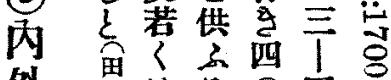
外男はる。四。 数其瓶 \% 週 以中>間 下干N保大 に分才存太 冾 却九りし元

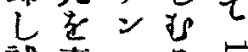
試充 一る

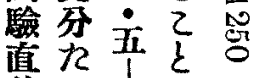
前牙士 汽し $\div$ 得 $b$ 鼎的 0 佂 態值踝其少 を古を法な 保に加学光 加入人汁漂

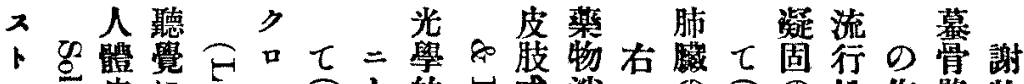

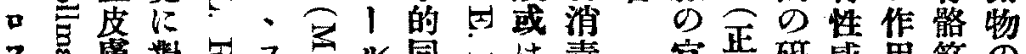

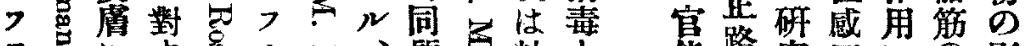

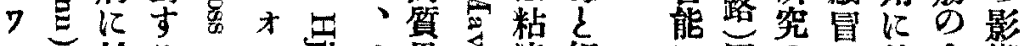

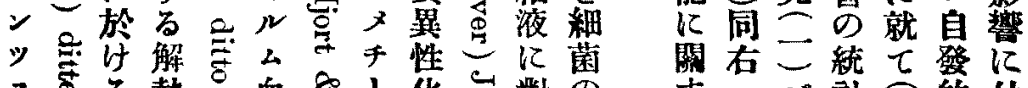

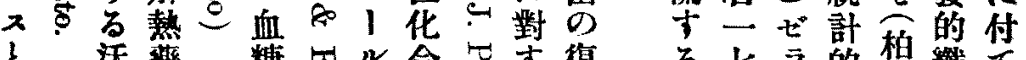

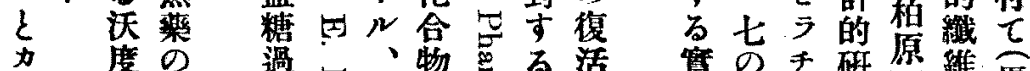

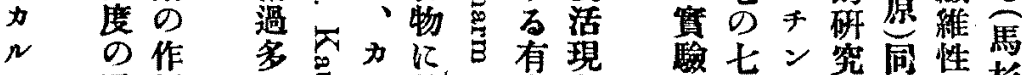

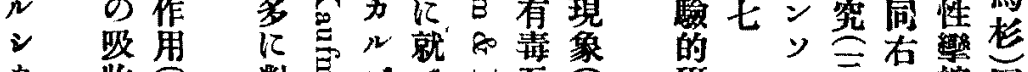

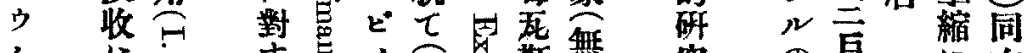

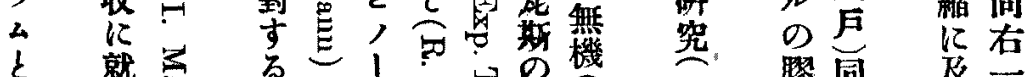

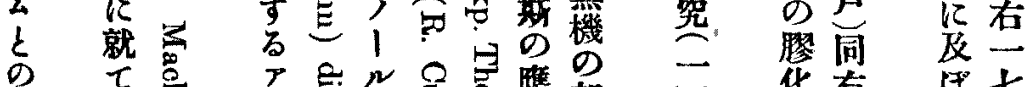

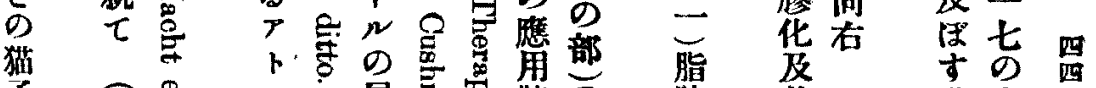

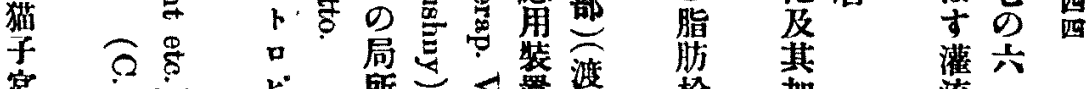

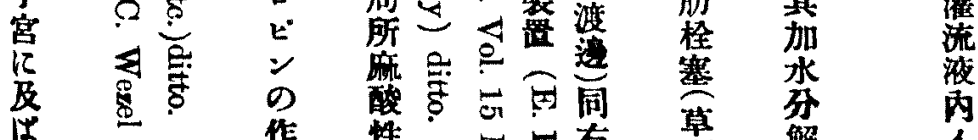

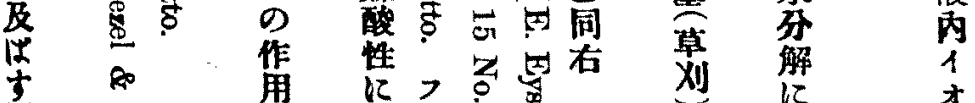

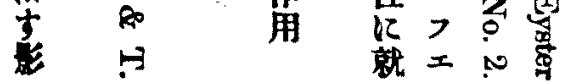


549)

椎

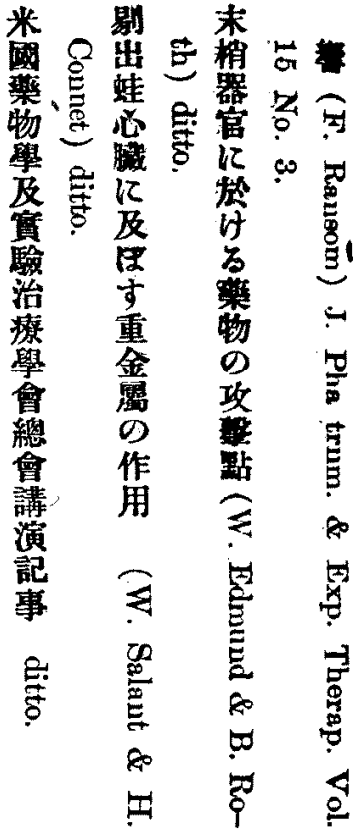

の○アしでの得三なが九東での付ふ 牛鐵ンて四下ら+

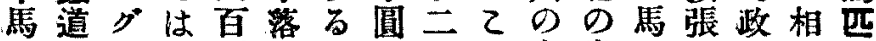

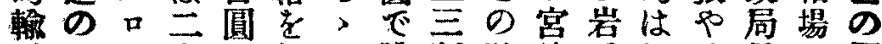

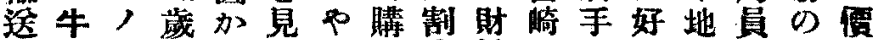
數馬マでらる5へ方界鹿责惡方は高格

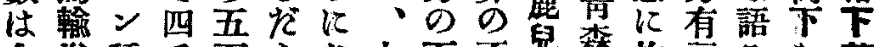

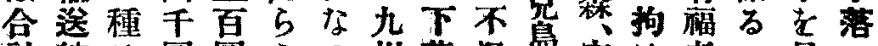
計統は圆圆 52 州落㫛品宮は者》見

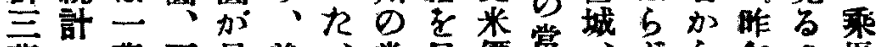

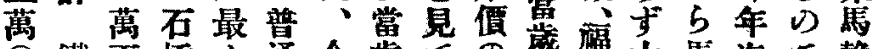

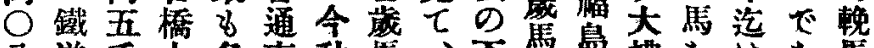

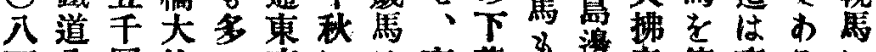

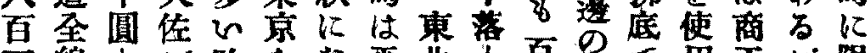

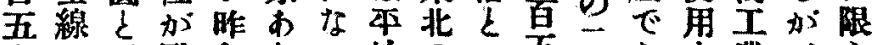

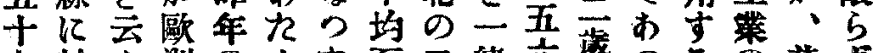

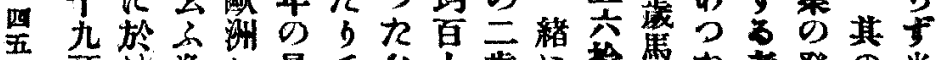
$\mid$

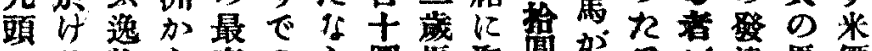

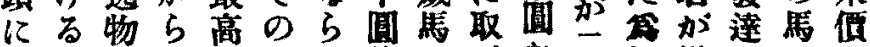

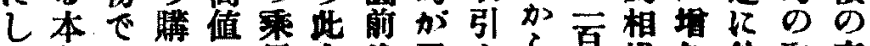

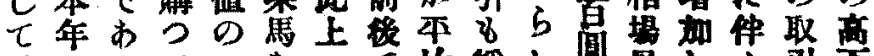

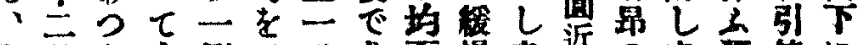

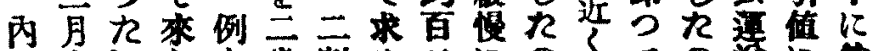

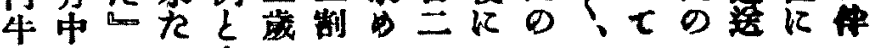

